\title{
PERUSTEKSTEJÄ VAPAASTA SIVISTYSTYÖSTÄ
}

K ansanvalistusseuralta ja Aikuiskasvatuksen Tutkimusseuralta on jälleen ilmestynyt uusi vapaan sivistystyön vuosikirja. Sille on annettu nimi "'Valistus, sivistys, kasvatus".

Kirjaan on koottu yhteensä 24 artikkelia kuudeltatoista vapaan sivistystyön klassikolta. Artikkelit on koottu neljään lukuun seuraavasti: 1. Perusteet ja käsitteet, 2. Valtio ja kansansivistystyö, 3. Aatteet ja organisaatiot ja 4. Aikuisten opettaminen ja oppiminen. Lisäksi kirjassa on perusteelliset johdantoartikkelit molemmilta toimittajilta Rainer Aaltoselta ja Jukka Tuomistolta.

Miksi vanhojen artikkeleiden esiinkaivaminen on koettu tarpeelliseksi? Tähän toimittajat vastaavat, että aikuiskasvatuksessa, kuten yleisesti yhteiskuntatieteiden piirissä yleensäkin juurille palaaminen koettiin tarpeelliseksi 1970-luvulla. Tuolloin kyllästyttiin "'suurteorioihin", , 'abstraktiin empirismiin" ja "testomaniaan". Klassikoiden tekstien tuntemuksen katsotaan lisäksi kuuluvan alan perussivistykseen. Siksi kirja päätettiin tehdä. Artikkeleiden etsimiseen ja kirjan toimittamiseen kului runsaat 10 vuotta.

K etkä sitten kuuluvat kirjan mukaan vapaan sivistystyön klassikkoihin? He ovat: J.V. Snellman, Niilo Liakka, Zachris Castrén, T.I. Wuorenrinne, Urpo Harva, Kosti Huuhka, YrjöSakari Yrjö-Koskinen, Yrjö Länsiluoto, Santeri Alkio, Aukusti Dahlberg, Väinö Voionmaa, Yrjö Kallinen, Severi Nyman, Ville Lehtola, R.H. Oittinen ja Helle Kannila. Nimiluettelo on edustava, mutta olisiko esimerkiksi Arvo Inkilä vielä mahtunut mukaan?

Kuten toimittajat itsekin toteavat, kirjan artikkelit vaihtelevat teoreettiselta merkitykseltään. Omana aikanaan ne ovat kuitenkin kaikki olleet
Valistus, sivistys, kasvatus. Kansanvalistusseura ja Aikuiskasvatuksen Tutkimusseura 1991.

tärkeitä puheenvuoroja. En ryhdy kommentoimaan kaikkia artikkeleita, vaan poimin esille ainoastaan muutaman, joita itse pidän edelleenkin tärkeinä.

Kirjan mielenkiintoisin anti löytyy kahdesta ensimmäisestä luvusta. Ensimmäisen luvun artikkeleista pidän erityisen mielenkiintoisina seuraavia kolmea artikkelia väheksymättä mitenkään muidenkaan merkitystä.

T.I. Wuorenrinteen artikkelissa "'Kansanvalistuksesta kansansivistykseen" vuodelta 1927 esitellään hyvin, miksi käsite valistus haluttiin vaihtaa sivistykseen. Sen sijaan, että oppilaille jaetaan valmiiksi pureksittua tietoa, heille pitää opettaa omakohtaista tiedonhankintaa. Urpo Harvan artikkelissa "Kansansivistystyön käsite", vuodelta 1942 perustellaan kansansivistystyön liittäminen kasvatuksen teoreettiseen viitekehykseen sivistysajattelun sijasta. Kosti Huuhkan artikkelissa "Vapaa kansansivistystyö ja aikuiskasvatus" vuodelta 1960 osoitetaan, miksi aikuiskasvatuksen käsite on syytä ottaa kaikkea aikuiskasvatustoimintaa kuvaavaksi yleiskäsitteeksi.

$\Gamma$ oisen luvun kahdessa ensimmäisessä artik1 kelissa sanotaan mielestäni kaikki olennainen vapaan sivistystyön ja valtion suhteista. Nämä artikkelit ovat Niilo Liakan kirjoitus vuodelta 1919 ' Vapaa kansanvalistustyö IV' ja Zachris Castrénin kirjoitus vuodelta 1929 "'Valtio ja vapaa kansansivistystyö’.

Kolmannessa luvussa käsitellään aatteita ja organisaatioita. Koska näillä artikkeleilla on aikoinaan perusteltu jonkin vapaan sivistystyön muodon tarpeellisuutta, ne ovat luonteeltaan enemmänkin ohjelmajulistuksia kuin tieteellisiä artikkeleita. Poikkeuksen tekee Castrénin artikkeli 
' 'Työväenopistojen sivistystehtävästä' vuodelta 1919, jolla on myös teoreettista merkitystä.

Neljäs luku, joka käsittelee opettamista ja oppimista, paljastaa mielestäni hyvin, että aikuisia koskevan oppimisteorian kehittely on jäänyt vapaassa sivistystyössä taka-alalle. Kyseisen luvun artikkelit sisältävät kyllä muutamia käytännön ohjeita sekä opettajille että opiskelijoille, mutta mitään kunnollista oppimisteoriaa niiden taus- talta on vaikeaa löytää. Siihen alettiin kiinnittää huomiota esimerkiksi yliopisto-opetuksessa vasta joskus 1960-luvun lopulta alkaen.

K aiken kaikkiaan kirja on kuitenkin hyvin 1 tarpeellinen jokaiselle, joka on kiinnostunut vapaan sivistystyön historiasta. Se puolustaa hyvin paikkaansa käsikirjana ja täydentää sopivasti muita alan historiaa käsitteleviä teoksia.

\section{JUHA SIHVONEN}

